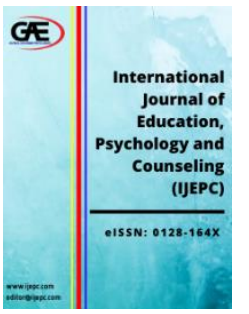

\author{
INTERNATIONAL JOURNAL OF \\ EDUCATION, PSYCHOLOGY \\ AND COUNSELLING \\ (IJEPC) \\ www.ijepc.com
}

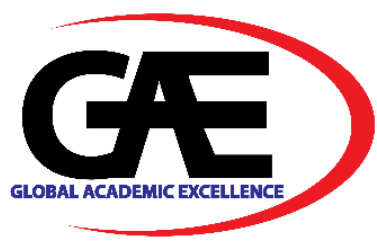

\title{
RELATIONSHIP BETWEEN THE LEVEL OF KNOWLEDGE ABOUT COVID-19 AND IMPLEMENTATION OF MOVEMENT CONTROL ORDER (MCO) AMONG THE MEMBERS OF THE ALLIED HEALTH SCIENCE IN THE TRAINING INSTITUTE OF THE MINISTRY OF HEALTH MALAYSIA, KOTA KINABALU (ILKKM KK)
}

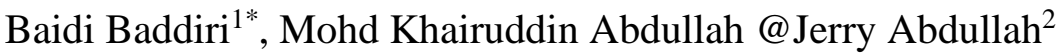 \\ 1 Training Institute of the Ministry of Health Malaysia (ILKKM KK) \\ Email: baidibaddiri74@gmail.com \\ 2 University Malaysia Sabah (UMS) \\ Email: khair@ums.edu.my \\ * Corresponding Author
}

\section{Article Info:}

Article history:

Received date: 04.07.2021

Revised date: 12.08 .2021

Accepted date: 08.09.2021

Published date: 15.09.2021

To cite this document:

Baddiri, B., \& Abdullah, M. K. (2021). Relationship Between The Level Of Knowledge About Covid-19 And Implementation Of Movement Control Order (MCO) Among The Members Of The Allied Health Science In The Training Institute Of The Ministry Of Health Malaysia, Kota Kinabalu (ILKKM KK). International Journal of Education, Psychology and Counselling, 6 (42), 440-454.
Abstract:

Safety and Healthcare system become the government's main agenda, especially when the country is facing a critical global epidemic crisis, known as the transmission of the third wave of COVID-19. The transmission of COVID-19 wave with a very sharp increase in cases on October 12, 2020, where the number of cases was detected increase drastically compare to the first wave of epidemic compilation. The Country of Sabah is a state that reports so many cases of daily infections that up to 600 active cases are detected every day and subsequently places the state of Sabah become a red zone. This might be due to a lack of knowledge among the community, especially after the state election. Therefore, the emphasis on knowledge level is an important aspect in curbing the transmission of COVID-19. Thus, this study was conducted to find out what is the level of knowledge about COVID-19 and the Movement Control Order (MCO) as well as to identify the relationship between these two variables in breaking the chain of COVID-19 transmission, especially among the ILKKM KK staff. The study design was applying quantitatively in the research methodology, by the implementation of questionnaires through surveys, while sample randomize sampling was used as a sampling method with a total of 267 respondents consisting of ILKKM KK staff. Analysis of instrument evaluation and sampling methods is also discussed in this study. The results showed that the patient's level of knowledge about COVID-19 was at a high level with a mean value $=3.902, \mathrm{SD}=0.423$. However, the level of knowledge about $\mathrm{MCO}$ is a moderate level with a mean value $=3.631$, SD 


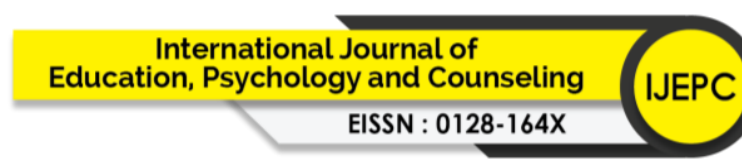

Volume 6 Issue 42 (September 2021) PP. 440-454

DOI 10.35631/IJEPC.642035

DOI: $10.35631 /$ IJEPC.642035.

This work is licensed under $\underline{\mathrm{CC} B Y}$ 4.0 (a)
$=0.323$. Meanwhile, correlation analysis showed there is a strong relationship between knowledge of COVID-19 and knowledge of MCO with correlation value $r=0.79, p>0.05$. Thus, the results of this analysis show that there is a strong relationship between the knowledge level of COVID-19 and MCO in deciding the chain of infection of COVID-19, especially among the ILKKM KK residents.

Keywords:

Relationship of Knowledge Level of COVID-19 and Knowledge Level of Movement Control Order (MCO)

\section{Introduction}

Currently, the state of Sabah is facing a critical global epidemic crisis, which is the transmission of the third wave of COVID-19. Daily statistics in mid-October saw a sharp increase in cases started on October 12, 2020, where the number of cases doubled compared to the spread of the first wave when the epidemic began to hit Malaysia (Noor Hisyam, 2020 \& Abdul Hamid, 2020 ). Sabah reports so many cases of daily infections that up to 600 active cases are detected every day and thus Sabah is declared as a red zone (Ismail Sabri, 2020). This increase also occurred in the states in Peninsular Malaysia started with the detection of the Benteng case in a prison in the state of Kedah and the infection had spread to several nearby states including Putrajaya which is also declared a red zone.

Following the high number of cases reported daily, the government through Nartional Security Council announced the Conditional Movement Control Order (CMCO) to reduce the total infection of COVID-19 in Sabah starting October 14, 2020 which is expected to end on October 26, 2020 (Ismail Sabri, 2020). This CMCO instruction also covers several states in Peninsular Malaysia. In addition, the threat of COVID-19 also claimed lives with the number of deaths of 3-5 people per day reported, which the number of deaths increasing to $193(0.87 \%)$ reported as of October 20, 2020 (Ismail Sabri, 2020). Movement Control Order is one of the best methods in supporting the government's implementation to reduce the spread of COVID19 infection to green zone areas (Soumya, 2018; Tedros, 2020; Noor Hisyam, 2020 \& Ismail Sabri, 2020). According to Jinping (2020), is curcial to control the movement of people to reduce contact with health or the carrier individual.

\section{Problem Statement}

At this moment, the Sabah government under supervision of the Ministry of Health Malaysia $(\mathrm{MOH})$ has implemented Conditional Movement Control Order (CMCO) in Sabah. This is base on data collection found that between 400 to 600 news cases was detected continously within three days of observation (Noor Hisyam, 2020 \& Sabri, 2020). Implementation of Conditional Movement Control Order (CMCO) in Sabah as one of the main preventive measures in curbing the spread of COVID-19 (Soumya, 2018; Tedros, 2020 \& Ismail Sabri, 2020 ). According to the World Health Organization (WHO), the best way to decide or control the COVID-19 pandemic is to carry out the Movement Control Order (MCO) instructions in addition to practicing social imprisonment, washing hands with soap or sanitizer for at least 20 seconds and avoid large scale gatherings (Tedros, 2020 \& Jinping, 2019). The practices proposed by the World Health Organization (WHO) are seen to be very effective in severing the COVID19 infection chain. So far almost all countries affected by COVID-19 have implemented these 


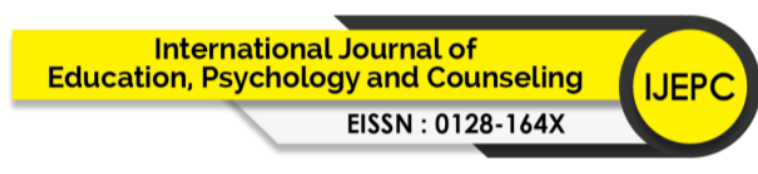

Volume 6 Issue 42 (September 2021) PP. 440-454

DOI 10.35631/IJEPC.642035

recommendations as it has been shown to reduce the transmission of COVID-19 (Soumya, 2018; Tedros, 2020 \& Ismail Sabri, 2020).

However, some communities or residents of Sabah still fail or disobey this directive which disturbs the government's efforts and increases the number of daily infections as reported on television or electronic media through social media (Noor Hisyam, 2020 \& Abdul Hamid, 2020). Following the increase in cases of COVID-19 infection in Sabah, the Malaysian Police Commissioner also confirmed that the increase in arrest statistics for disobeying orders is increasing despite a fine of RM 1000 (Abdul Hamid, 2020). Recently, the Minister of Home Affairs further enforced the Movement Control Order (MCO) by arresting and bringing offenders to court as well as imposing heavier punishments such as imprisonment for those convicted (Ismail Sabri, 2020). The government's efforts will not be successful if the community does not understand the steps to break the COVID-19 infection chain (Noor Hisyam, 2020).

Nonetheless, many Sabahans came forward for voluntary examination or treatment (Noor Hisyam, 2020 \& Abdul Hamid, 2020). However, there are still many disobedient people in this state and do not understand the situation we are experiencing at this time. These groups are vulnerable to COVID-19 infection (Noor Hisyam, 2020 \& Abdul Hamid, 2020). The reluctance to come forward or cooperate with the health sector is a challenge and a threat to the community in this country as they can infect other person or their family members (Noor Hisyam, 2020). In addition, these individuals are also able to create new clusters and further expand the chain of infection COVID-19 (Ismail Sabri, 2020).

The issue of COVID-19 transmission does not just end there. According to a report by the Ministry of Health Malaysia through the Royal Malaysian Police (RMP) found, although the government has issued instructions or regulations Standard Operation Procedure (SOP) to deal with the spread of COVID-19, but still many individuals travel locally or interdistricts and then return while bringing this virus into other districts or green zones. These groups are also the ones who refuse to undergo screening and creates new clusters. The reality is that whoever we are will not be exempted from this epidemic as long as we do not comply with the instructions issued by the MOH, RMP or the National Security Council (NSC) (Noor Hisyam, 2020; Abdul Hamid, 2020 \& Ismail Sabri, 2020). At the same time, as the frontliner is struggling against COVID-19, there are still groups of individuals holding secret group meetings. Such face-toface meetings are believed to be the transmission medium for COVID-19.

COVID-19 disease is also a disease that easily spreads from individual to individual through the secretion of body fluids or droplets from infected individuals to healthy individuals (Tedros, 2020 \& Noor Hisyam, 2020). Dissemination through this method includes direct contact with infected individuals, such as shaking hands, touching equipment or surfaces contaminated with this virus (Peter, 2020). In addition, the virus also spreads from oral secretions such as sneezing, coughing or talking (Jane, 2020). Thus, one-meter physical imprisonment is recommended by the medical and health experts worldwide (Tedros, 2020; Margaret, 2020 \& Adham Baba, 2020).

If observed, there are still many in our society who do not understand the physical distance (Tedros, $2020 \&$ Noor Hisyam, 2020). This is clearly observed by their presence in crowded places such as wet markets and public places such as banks, bus stops, supermarkets, health 


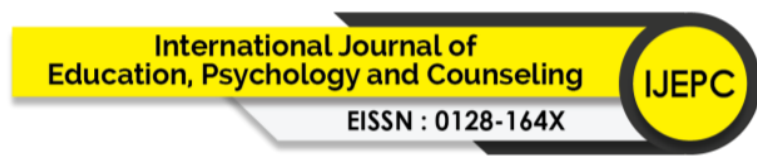

Volume 6 Issue 42 (September 2021) PP. 440-454 DOI 10.35631/IJEPC.642035

clinics, hospitals, police stations and other premises which are often the focus of the public (Noor Hisham, 2020 \& Abdul Hamid, 2020). Based on these observations, it is clear that preventive practices such as social imprisonment are not fully practiced by the community, apart from that the wearing of face masks in public places as recommended by the Ministry of Health Malaysia is still not fully implemented (Abdul Hamid, 2020 \& Adham Baba, 2020). Failure to do so will increase the risk of COVID-19 infection.

The statement of problems related to the spread of COVID-19 disease and the direction of the Movement Control Order (MCO) in this country has been detailed as described above. This problem if refined actually stems from the attitude or low level of knowledge about breaking the chain of disease COVID-19 which makes the disease quite difficult to curb. Thus, this study was conducted to find out what is the level of knowledge about COVID-19 and Movement Control Order (MCO) as well as to identify the relationship between the level of knowledge about COVID-19 and the importance of Movement Control Order (MCO) in the prevention of COVID-19 transmission.

Apart from that, this study also identifies suggestions related to preventive measures that need to be taken, especially among health personnel in the facilities of the Training Institute of the Ministry of Health Malaysia Kota Kinabalu, Sabah (ILKKM KK) to curb the COVID-19 incident that is affecting the state of Sabah in general. This study is also expected to be a guide or benchmark to local authorities in helping the community in line with the government's desire so that the community and the government can work together in overcoming and fighting this COVID-19 pandemic.

\section{Objectives}

\section{General Objectives}

This study was conducted to identify the level and relationship between the level of knowledge about COVID-19 and the Movement Control Order (MCO).

\section{Specific Objectives}

i. To dentify the socio-demographics of the respondents.

ii. To identify the level of knowledge about COVID-19 among respondents. iii. To identify the level of knowledge of the Movement Control Order (MCO). iv. To identify the relationship between the level of knowledge about COVID-19 and the Movement Control Order (MCO).

\section{Literature Review}

The epidemic is caused by a type of virus known as Coronavirus (Tedros, 2020). This pandemic has shocked the world where it started in a settlement known as Wuhan district in China (Tedros, 2020 \& Jinping, 2020). At first, the world community did not predict the occurrence of this disease as bad as they expected, instead the misconception of the World Health Organization (WHO) in curbing the spread of the disease ultimately adversely affected regional countries. In addition, the careless attitude of some countries in initiating control and prevention measures through local and international travel restrictions such as air, sea and land has caused the disease to spread rapidly to more than 220 countries worldwide so far. 


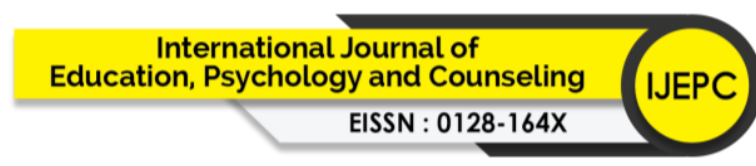

Volume 6 Issue 42 (September 2021) PP. 440-454

DOI 10.35631/IJEPC.642035

The COVID-19 pandemic has now infected more than 64 million people worldwide and has claimed more than 1.34 million lives and it is expected that this number will increase over time (Jinping, 2020). At this point, the world community is not sure when this catastrophe will end or can be fully addressed. According to Margaret (2020), many studies have been done so far to find a cure for this disease, but until now there is not a single drug or vaccine that can really control or treat COVID-19 disease. The latest Malaysian government has made an initial agreement with the Chinese government following the latest vaccine, the Pfizer's COVID-19 vaccine, but it is still disputed by some parties, especially the Malaysian Pharmaceutical Association. Thus, to further control the severity of the COVID-19 disease, the World Health Organization (WHO) issued a global statement and warning on preventive measures to be implemented, they argued that only by strengthening preventive measures could sever individual-to-individual infection and also between countries (Tedros, 2020 \& Jinping, 2019).

The COVID-19 pandemic is the deadliest viral infection in the history of the world compared to some global disease crises including Severe Acute Respiratory Syndrome (SARS), Middle East Respiratory Syndrome (MERScov), Nipah Virus, Human Immunodeficiency Virus (HIV), Ebola and several diseases that also contribute to world mortality statistics (Soumya, 2018 \& Jane, 2019). At this time COVID-19 disease has not yet been fully addressed. Infected patients will be treated according to the infection protocol on the respiratory tract or as symptomatic until the patient can form antibodies or the infection subsides on its own (Soumya, 2018 \& Tedros, 2020). In most cases, especially those at risk or co-morbid will end up dead. This is due to severe respiratory system failure (Adham Baba, 2020). Thus, the approach in this country is to control the spread of COVID-19 is by imposing control and prevention measures including the Movement Control Order (MCO) which has been implemented by the government (Muhyiddin, 2020 \& Ismail Sabri, 2020). Despite this, there are still many in the community who disobey the government's proposal that will eventually thwart efforts to end the COVID-19 pandemic in Malaysia in particular (Ismail Sabri, 2020).

Thus, in order to further control the transmission of COVID-19 infections. The World Health Organization (WHO) issued a global statement and warning on preventive measures to be implemented, they argued only by strengthening preventive measures such as the Movement Control Order (MCO) is the best action to control the transmission of COVID-19 infections. According to Jinping (2019) \& Tedros (2020), the Movement Control Order (MCO) capable of deciding the transmission of infection between individuals as well as between countries with other countries (Tedros, 2020 \& Jinping, 2019).

Currently, the government through the Ministry of Health Malaysia (MOH) has implemented the Movement Control Order (MCO) under Act 342. This Act came into force on March 8, 2020 as one of the main preventive measures in curbing the spread of COVID-19 (Noor Hisyam, 2020; Abdul Hamid, 2020 \& Ismail Sabri, 2020). However, some communities or residents of Malaysia still fail or disobey on this directive which ultimately thwarts the government's efforts and increases the number of daily cases of infection. This evidenced was reporting in the developmental of Covid-19 daily cases through television, electronic media or social media (Noor Hisyam, 2020 \& Abdul Hamid, 2020).

Similarly, according to the Malaysian Police Commissioner who confirmed the increase in arrest statistics for those who disobeyed the order is increasing despite the fine of RM 1000 imposed (Abdul Hamid, 2020). Recently, the Home Minister re-enforced the Movement 


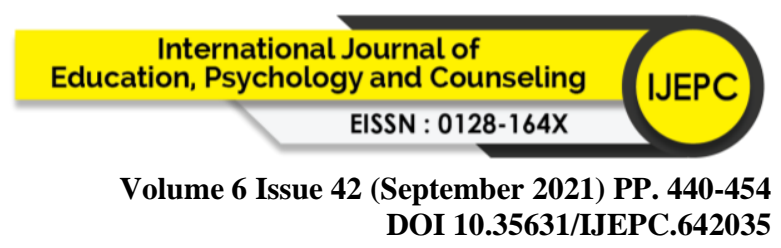

Control Order (MCO) by arresting and prosecuting offenders in court as well as imposing heavier punishments such as imprisonment for those convicted (Ismail Sabri, 2020). The government's hard work was in vain if the community lacks understanding of the measures to break the chain of COVID-19 infection (Noor Hisyam, 2020).

\section{Methodology}

In this study, researchers applied a non-experimental study design with a quantitative research approach. The design of such a study was chosen because it is suitable as required. In addition, the researcher also uses the descriptive research design method in cross-sectional. This method allows researchers to obtain information directly before analyzing the data obtained (Othman, 2010 \& Cohen, 2010). This design study is often used in social science studies because it is able to provide a quantitative explanation of a population by only studying samples from that population (Majid Konting, 2004 \& Sekaran, 2005). In this study, the researcher also used the questionnaire as a technique to obtaining information from selected respondents.

\section{Location}

This study was conducted at the Training Institute of the Ministry of Health Malaysia Kota Kinabalu (ILKKM KK). This location was chosen because of the limited movement of researchers due to the MCO being implemented which restricts travel around 10 kilometers radius only. This caused the researcher to decide to conduct a study where the researcher is actually working at the Training Institute of the Ministry of Health Malaysia Kota Kinabalu (ILKKM KK). This location was also chosen as the researchers argued that all personnel of the health sciences have knowledge of COVID-19 disease and MCO instructions, no matter where they are (Cohen, 2009 \& Othman, 2010). Thus, the location of the study is not an issue or a constraint in carrying out this study (Majid Konting, 2004).

\section{Population}

The study population is an important aspect to support the objectives of the study. The study population must be appropriate to the research question or problem as this group will receive the effects or implications of the results of the study findings (Creswell, 2009 \& Rosnarizah, 2010). In this study, the researcher prioritizes the samples in ILKKM facilities who works or learns only after considering the instructions of $\mathrm{MCO}$ and causes a limited study population. Therefore, in this study, the selected study population consists of Management and Professionals, 1 \& 11 Support Group as well as trainees in ILKKM KK. The estimated population of the study is between 750 to 800 people at a certain time, as there are still programs conducting practical sessions at the Practical Training Center.

\section{Samples}

Samples are individuals who are selected as they meet the required eligibility criteria. In this study, a total of 267 respondents will be selected through sample randomize sampling after meeting the required sample selection criteria. Sample randomize sampling technique is often used because this technique is simpler, targeted in addition to meeting the needs of the study (Othman, 2010). Meanwhile, the study sample consists of Management and Professionals, 1 \& 11 Support Group and trainees in ILKKM KK. Number of samples corresponding to the total population using ILKKM KK facilities. Since the number of study population is between 750 to 800 people at a given time, then the number of samples required is between 256 to 260 people based on the calculation of samples Krejic and Morgan 1970. This number which is more than 50 and less than 500 people is as suggested by Sekaran (2003). According to Sekaran 


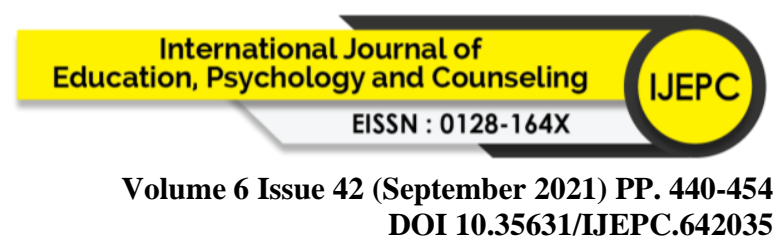

(2003), the number of samples required to conduct a single study should be more than 50 people and less than 500 people is sufficient. Meanwhile, according to Majid Konting (2004), stated that the number of respondents 30 is sufficient with the assumption that the normality distribution of data can be obtained when the number of respondents exceeds 30 people. The selection method of sample randomize sampling is used as the respondents are comprised of Management and Professionals, 1 \& 11 Support Group who are carrying out their duties as well as trainees undergoing training at ILKKM KK, during the MCO implemented in the state.

\section{Study Period}

\section{Research Period}

This study was conducted starting in mid-October 2020 and is expected to be completed within the next 3 months. This date was chosen as almost all categories including basic training and postbasic students have returned to college for the purpose of revision and final examination of the semester.

\section{Date Collection Period}

The data collection period starts at the end of October 2020 and is expected to be completed by mid-November 2020 .

\section{Inclusive Criteria}

Includes categories of health science personnel aged 18 and above and not exceeding 60 years. In addition, they must have the skills to speak, read and understand and be adept at writing in the Malay language. This criterion was chosen as this group is a high risk target group for COVID-19 infection.

\section{Exclusive Criteria}

Staff such as Security Guards, Gardeners and contract workers are not selected as they are not directly involved in training management other than the small number causing them not to belong to or possess the characteristics required in this study.

\section{Instrument Design}

Research instruments are the most important criteria in a study. The research instrument in the form of a questionnaire is used as the design of the instrument in this study. The research instrument is developed by the researcher as there is currently no proper stable instrument to measure the level of knowledge about COVID-19. The research instruments developed are customized according to the objective requirements in this study. Meanwhile, the questionsin the questionnaire form is built and formulated based on questions in the form of knowledge, signs and symptoms as well as preventive measures on COVID-19 disease. The items in the questionnaire are referred to two experts, namely a Medical and Family Health Specialist (FMS) as a content checker and another is a Professor from Universiti Malaysia Sabah (UMS) as a content and grammar checker. All items have a high-reliability value of between 0.7 to 0.8 (Creswell, 2009 \& Cohen, 2010).

The questionnaire form consists of three main parts; Part A: Socio-Demographics of Respondents with 4 categories, Part B: Levels of Knowledge (14 items), Signs and Symptoms (13 items) and Prevention of COVID-19 Transmission (14 items). Part C: Levels of Knowledge on Movement Control Order (MCO) (14 items). Sections B and C with questions 


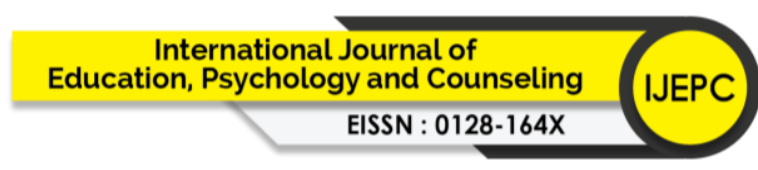

Volume 6 Issue 42 (September 2021) PP. 440-454

DOI 10.35631/IJEPC.642035

in the form of 'single choice items" "Strongly Disagree (Score 1), Disagree (Score 2), Uncertain (Score 3), Agree (Score 4) and Strongly Agree (Score 5)".

\section{Ethical Issues}

This study requires the approval and actual permission of the director as the Head of Department at ILKKM KK. Each questionnaire will be accompanied by a form of permission that does not need to be signed by each respondent before answering the questionnaire. The questionnaire form is provided in two versions, the first version is online and the second version is distributed. Respondents are given the option of answering the questionnaire according to their convenience. The questions used in the instrument do not require attention either sensitivity or racial issues. Every piece of information provided by the respondents is confidential and will only be used for academic purposes only.

\section{Analysis Study}

All data obtained will be analyzed using Statistical Package for Social Sciences (SPSS). Descriptive analysis is used to obtain score values for knowledge as well as demographic analysis while inference analysis is used to identify the level of relationship strength. Next, statistics and results are tabulated in the form of diagrams, tables, bar graphs or pie charts for the evaluation process and a graphical representation of the results obtained.

\section{Data Collection Methods}

The data collection method is based on a questionnaire that was distributed to 400 respondents at the end of October 2020 and finished in mid-November 2020. The questionnaire will be examined and reviewed one by one and only the truly perfect questionnaire will be analyzed, questionnaires that do not meet the required criteria will be removed and not used as detailed data. Next, all the raw scores will be included in the master score sheet to be tabulated before analysis.

\section{Pilot Study}

A pilot study session was conducted in early May 2020. This pilot study was conducted at the Emergency Department of Kinarut Health Clinic with a total of 30 samples randomly selected. A pilot study was conducted as a first step to find out the suitability of the items used as questions in the questionnaire. Inappropriate items will be improved or dropped and only questions which meet the criteria will be used in the actual study.

\section{Definition of Terms}

i. COVID-19 - In this study it is referred as a pandemic disease. COVID-19 disease is a disease caused by infection from a group of Corona viruses that were previously harmless to humans which now infect humans (Soumya, 2018 \& Tedros, 2020). The disease is believed to come from poultry and enter the human body systemduring food products operation from poultry that are not handled properly (Jinping, 2020 \& Jane, 2019).

ii. Movement Control Order (MCO) -In this study it means restriction of movement to deal with epidemics (Ismail Sabri, 2020). Meanwhile, according to Abdul Hamid (2020), MCO is a restriction on movement imposed on a group, community or a country due to disease outbreaks as found in the Police Act 1967. 


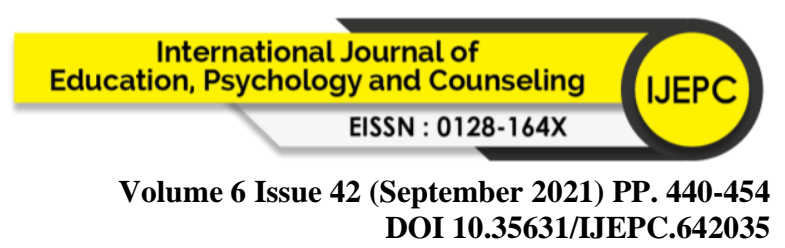

iii. Prevention of COVID-19 Transmission - In this study it means the level of knowledge on how to prevent COVID-19 infection. According to Tedros, (2020); Margaret, (2020) \& Adham Baba, (2020), physical incarceration, wearing face masks in public places and frequent hand washing are one method to prevent from being infected with COVID19.

\section{Limitation}

Among the limitations of the study to be expected is a limited period of time that is during the implementation of the Movement Control Order (MCO) only. In addition, the Movement Control Order (MCO) restricts the movement of researchers to expand area coverage of the study. Meanwhile, this study requires each respondent to answer honestly based on their level of knowledge of the Movement Control Order (MCO) instructions. Thus, the findings of the analysis are completely dependent on the honesty of the respondents in providing feedback. The number of samples is only focused on the samples conducting training or working in the area of the Training Institute of the Ministry of Health Malaysia Kota Kinabalu (ILKKM KK). Therefore, generalization is only suitable to be done at ILKKM KK only.

\section{Findings and Discussion}

\section{Respondent Background}

The table below describes the demographic characteristics of the respondents. Data are obtained and analyzed based on the information filled in by the respondents in part A of the questionnaire. In this section is all of the personal information of the respondents such as, Gender, Age, Level of Education and Internet Access.

Table 1: Demographic Characteristics of Respondents

\begin{tabular}{llcc}
\hline No. & Dimension & Frequency & Percentage \\
\hline \hline 1. & Gender & & \\
& 1. Male & 89 & 33.3 \\
& 2. Female & 187 & 66.7 \\
2. & Total & 267 & 100 \\
& Age & & \\
& 1. Below 30 years old & 168 & 63.1 \\
2. 31-40 years old & 53 & 20 \\
3. Above 41 years old & 46 & 16.9 \\
3. & 267 & 100 \\
& Education Level & & \\
& 1. Secondary School & 144 & 54.1 \\
2. Diploma & 94 & 35 \\
3. Degree & 29 & 10.9 \\
& Total & 267 & 100 \\
Internet Access & & \\
1. Strong & 85 & 31.4 \\
2. Moderate & 165 & 62 \\
3. Weak & 17 & 6.6 \\
& Total & 267 & 100 \\
\hline
\end{tabular}




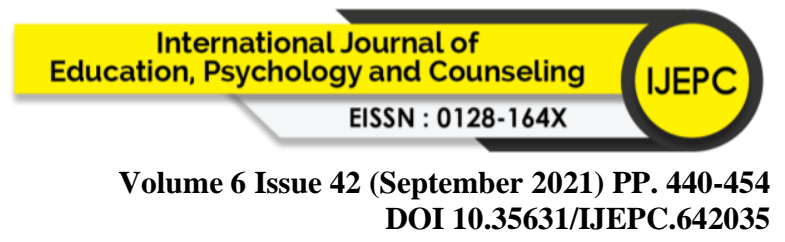

Table 1 above shows an analysis of the demographic characteristics of the respondents. In this study a total of 200 respondents have given their feedback. Distribution of respondents based on gender, namely Male $\mathrm{n}=89,(33.3 \%)$ and Female $\mathrm{n}=187,(66.7 \%)$. Next, respondents aged 30 years and below, a total of $n=168$ people $(63.1 \%), 31-40$ years, a total of $n=53$ people $(20 \%)$, while 41 years and above, a total of $n=46$ people $(16.9 \%)$. For Education Level, respondents with Secondary School qualifications are $\mathrm{n}=144$ (54.1\%), while Diploma Level $\mathrm{n}=94(35 \%)$, and Degree Level is $\mathrm{n}=29(10.9 \%)$. Meanwhile, Table 1 above also explains about internet access among respondents, Strong $n=85(31.4 \%)$, Moderate $n=165(62 \%)$, and Weak $\mathrm{n}=17(6.6 \%)$.

Table 2: Additional Information

\begin{tabular}{|c|c|c|c|}
\hline No. & Items & (n) & $(\%)$ \\
\hline 1. & $\begin{array}{l}\text { Have you ever been given a health education about } \\
\text { COVID-19 delivered by health staff. }\end{array}$ & 223 & 83.5 \\
\hline 2. & $\begin{array}{l}\text { Have you ever heard of health promotion } \\
\text { about COVID-19. }\end{array}$ & 244 & 91.4 \\
\hline 3. & $\begin{array}{l}\text { How do you get important information about } \\
\text { COVID-19. } \\
\text { 1. Sharing with friends. } \\
\text { 2. Through Health Staff. } \\
\text { 3. Through mass media or electronic (social) media. }\end{array}$ & $\begin{array}{l}155 \\
156 \\
257\end{array}$ & $\begin{array}{l}58.1 \\
58.4 \\
96.3\end{array}$ \\
\hline
\end{tabular}

Table 2, above describes the additional information needed while conducting this study. This information is important to know the status of how information about COVID-19 is obtained by the respondents. It includes health education on COVID-19 delivered by health staff $\mathrm{n}=$ $223(83.5 \%)$, To listen to health promotion is $\mathrm{n}=244(91.4 \%)$, and obtains important information about COVID-19 through Sharing with friends $n=155(58.1 \%)$, Health Staff $n=$ $156(58.4 \%)$, and through mass media or electronic (social) media $\mathrm{n}=257(96.3 \%)$.

\section{Analysis}

The results of the data analysis are based on the mean score value to determine the level of knowledge about COVID-19 and Movement Control Order (MCO) among ILKKM KK staffs who carry out their duties and use services and training at ILKKM KK.

Table 3: Level of Knowledge About COVID-19

\begin{tabular}{lcccc}
\hline \hline & N & Mean & SD & Level \\
\hline \hline Level knowledge & & & & \\
about COVID-19 & 267 & 3.895 & .423 & High \\
Valid N & 267 & & & \\
\hline \hline
\end{tabular}


Volume 6 Issue 42 (September 2021) PP. 440-454

Table 4: Dimension of Level of Knowledge About COVID-19

DOI 10.35631/IJEPC.642035

\begin{tabular}{llllll}
\hline \hline No. & \multicolumn{1}{c}{ N } & Mean & SD & Level \\
\hline \hline 1. & General knowledge & & & \\
& about COVID-19 & 267 & 3.902 & .332 & High \\
2. & Sign \& Symptoms & 267 & 3.971 & .453 & High \\
3. & Control \& Prevention & 267 & 3.812 & .224 & High \\
& & & & \\
\hline \hline
\end{tabular}

Table 3, above shows the overall data on the analysis of the level of knowledge about COVID19 disease. Meanwhile, Table 4, above showed the analysis for each dimension in the level of knowledge. The results of total analysis shown that the level of knowledge about COVID-19 disease is at a high level with a mean score value $=3.895, \mathrm{SD}=0.423$ (Table 3 ). This is because of the analysis for each dimension of General Knowledge is at a high level with a mean score value $=3.902, \mathrm{SD}=0.332$. Furthermore, the dimensions for Signs and Symptoms also have a mean score value $=3.971, \mathrm{SD}=0.453$ is also at a high level (Table 4). Meanwhile, the mean score value for Control and Prevention is at a high level with a mean score value $=3.812$, SD $=.224$. The results of this analysis shown that ILKKM KK staffs also have a high level of knowledge about COVID-19 disease.

Table 5:Level of Knowledge of Movement Control Order (MCO)

\begin{tabular}{llllll}
\hline \hline & & N & Mean & SD & Level \\
\hline \hline Level of Knowledge & of & & & & \\
MCO & & 267 & 3.631 & .323 & Moderate \\
Valid N & 267 & & & \\
\hline \hline
\end{tabular}

Table 5, above shows the overall data on knowledge level analysis on Movement Control Order (MCO). The results of the analysis showed that the overall level of knowledge about the Movement Control Order $(\mathrm{MCO})$ is at a moderate level with a mean score value $=3.631$, SD $=0.323$. This finding shown that many of the KK ILKKM staff are still new to the Movement Control Order (MCO) Act introduced by the government.

\section{Relationship Analysis}

Correlation analysis is an analysis that is often used to see if there is a relationship between the study variables. Correlation analysis is used to identify the strength of a relationship or the direction of a relationship. The study of correlation analysis is used to see if there is a relationship between the level of knowledge about COVID-19 with the level of knowledge about Movement Control Order (MCO). In this study, the total mean score of level of knowledge about COVID-19 with total mean score of level of knowledge about Movement Control Order are analyze togather.

Table 6: Correlation Test Analysis - Relationship between COVID-19 Knowledge Level with Movement ControlOrder (MCO).

\begin{tabular}{llll}
\hline \hline & COVID-19 & & MCO \\
\hline \hline \multirow{2}{*}{ COVID-19 } & Pearson Correlation & 1 & .785 \\
& Sig. (2-tailed) & & .021 \\
& $\mathrm{~N}$ & 267 & \\
\hline \hline
\end{tabular}




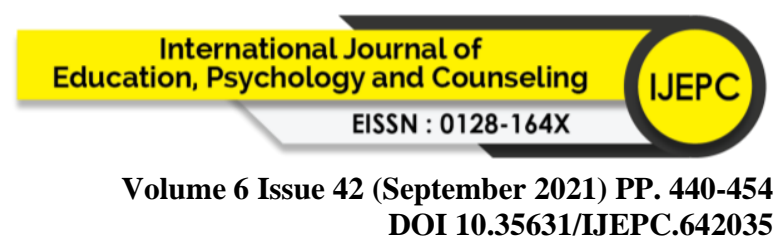

Table 6, above shows the values for the correlation coefficient (r). The results of the analysis showed that the correlation value for the level of knowledge about COVID-19 with the level of knowledge about the Movement Control Order (MCO) is equal to $\mathrm{r}=.79, \mathrm{p}>0.05$ is strong and significant (Cohen \& Manion, 2004). The results of the correlation analysis explain that there is a strong and positive relationship between the level of knowledge about COVID-19 and the level of knowledge about the Movement Control Order (MCO). This analyisis explained that ILKKM KK residents understand that these two variables play an important role as the best method to sever the COVID-19 infection chain.

\section{Discussion}

The above findings explain that the level of knowledge of respondents about COVID-19 disease is at a high level. This is due to only a small number of $16.5 \%$ of respondents stated that they have never heard a talk on COVID-19 disease delivered by health staff. Meanwhile, $91.4 \%$ of respondents stated that they have heard of health promotions through sharing with friends. In addition, a large number of respondents agreed and stated that to obtain important information about COVID-19 disease, they used the mass media as the main channel of choice. According to Johari and Raja (2012), modern citizens have made electronic media, especially social media, a medium to obtain information, share views and channel important information as well as false information (Salleh, 2018).

Furthermore, the level of knowledge about COVID-19 among the respondents is at a high level because at this time there are many local health organizations as well as international health organizations that provided information and general knowledge about COVID-19 disease (Tedros, 2020). According to (Jane, 2020) the COVID-19 pandemic is a new phenomenon therefore, the world community needs some time to understand and produce the latest studies on it. In addition, the wise measures of the Ministry of Health Malaysia in promoting health care to the optimum level make a high level of knowledge about the signs and symptoms of COVID-19 is a factor why the level of knowledge about COVID-19 is at a high level. At this time many of the respondents are able to identify the main signs of this disease including fever, cough, flu, difficulty breathing and death (Margaret, 2020). The level of knowledge of the respondents is also at a high level is also due to the respondents becoming aware and rejecting practices and attitudes carelessly and less sensitive to COVID-19 disease control and prevention measures when we are at war with the COVID-19 pandemic crisis at this time (Soumya, 2018 and Jane, 2019).

However, the discussion of the level of knowledge on the Movement Control Order (MCO) found that the level of knowledge of the respondents is at a moderately high level. This is a common occurrence where something new is quite difficult to accept let alone it greatly affects daily life (Ismail Sabriet, al. 2010a). However, most of the respondents have been diligent to understand the Movement Control Order (MCO) and strive to face it besides considering it as a difficult choice but has to be implemented by the government in order to maintain the unity of the people. (Ismail Sabri, 2020 and Noor Hisyam, 2020). The level of knowledge about the Movement Control Order (MCO) is at a moderately high level is also due to the change in life to new norms encourage respondents to try to deepen the understanding of Movement Control Order (MCO) (Ismail Sabri, 2020). 


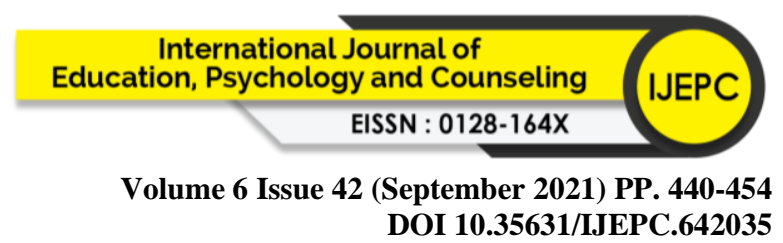

The results of the study on the relationship found that there is a significant relationship between the level of knowledge about COVID-19 with the level of knowledge about the Movement Control Order(MCO). This is because the respondents actually understand the COVID-19 problem faced at this time is very critical besides, the respondents are also aware and agree with the government's action by imposing a Movement Control Order (MCO) as the best alternative in severing the COVID-19 infection chain. According to Noor Hisyam (2020), the community must comply with the wishes of the government, and in doing so all government efforts can be implemented well and effectively to ensure that the health of the people can be maintained at an optimal level. Thus obedience to the Movement Control Order (MCO) is the key to success in combating this situation. This statement is also supported by Ismail Sabri (2020) and IGP (2020), who stressed that adherence to the Movement Control Order (MCO) can not only reduce COVID-19 infection but it also helps in maintaining the well-being of the global community in general by imposing a Movement Control Order (MCO).

Another review of the relationship between COVID-19 and the Movement Control Order (MCO) is also supported by the International Health Agency. According to Tedros (2020), COVID-19 is a disease that easily spreads from individual to individual, thus limiting direct contact between individuals can break the chain of infection. Therefore, he stressed that the Movement Control Order (MCO) should be implemented as the main step in curbing the spread of COVID-19. Meanwhile, Margerat (2020), thinks that the Movement Control Order (MCO) is the main and last action that needs to be implemented so that the COVID-19 pandemic can be stopped. The discussion on the relationship clearly indicates the existence of a strong foundation which states that there is a strong relationship between knowledge of COVID-19 and the Movement Control Order (MCO).

\section{Conclusion}

As a result of the discussion as above, it can be concluded that the level of knowledge about COVID-19 and the Movement Control Order (MCO)among respondents needs to be further strengthened. This is important to ensure that ILKKM KK staffs really understand the issues they are facing, and it is important to comply with the government's instructions to implement the Movement Control Order (MCO) because both of these factors if neglected can affect health, economy, social and change old life patterns to new norms. The emphasis on living the new norms and adherence to the Movement Control Order (MCO) is expected to help the government and the world community in breaking the chain of COVID-19 infection. Thus, there are some suggestions and improvements which are to further strengthen and update the existing acts and regulations on COVID-19 and Movement Control Order (MCO), in addition to improving and diversifying methods to increase the level of knowledge about COVID-19 and Movement Control Order (MCO) among the general public. This includes enhancing online health talks through mass media, electronic media at a regular or periodic rate so that this important information can reach the target group as desired. Similarly, information on the Movement Control Order (MCO) instructions is implemented through the same medium as many of the respondents have good internet access. (SKMM, 2020).

\section{References}

Adham Baba, The Health Minister "who will lead fight against Covid-19?". Malay Mail. 9 March 2020. Retrieved 9 March 2020.

Adham Baba The Health Minister "terajui Kementerian Kesihatan". Astro Awani. 2 April 2020. Retrieved 2 April 2020 


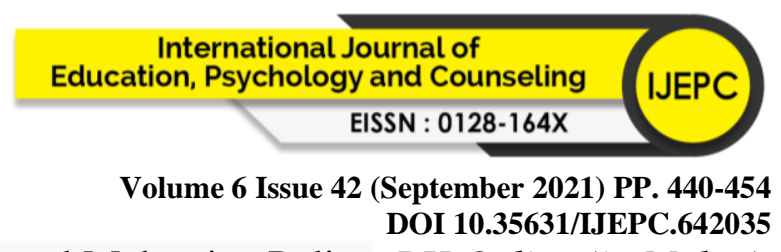

Abdul Hamid Bador Inspector-General of the Royal Malaysian Police. BH Online (in Malay). 9 March 2020. Retrieved 11 March 2020.

Akin, A. 2012. The relationships between internet addiction, subjective vitality, and subjective happiness. Journal Of Cyberpsychology, Behavior and Social Networking. 15(8): 404408.

Bargh, J.A dan Mckenna K.Y.(2004) The Internet And Social Life. Journal Of Annual Reviews Psychology.

Buku Maklumat Statistik (Q4-2013) dlm. Suruhanjaya Komunikasi dan Multimedia Malaysia. 2013.

Bordi Licia, Nicastri Emanuele, Scorzolini Laura, Di Caro Antonino, Capobianchi Maria Rosaria, Castilletti Concetta, Lalle Eleonora, on behalf of INMI COVID-19 study group and Collaborating Centers2. Differential diagnosis of illness in patients under investigation for the novel coronavirus (SARS-CoV-2), Italy, February 2020. Euro Surveill. 7917.ES.2020.25.8.2000170 2020;25(8):pii=2000170. https://doi.org/10.2807/1560-

C. I. Paules, H. D. Marston, and A. S. Fauci, Coronavirus infections-More than just the common cold, JAMA, 323(8):707-708, 2020 DOI: https://doi.org/10.1001/jama.2020.0757 Correlation of Chest CT and RT-PCR Testing in Coronavirus Disease 2019 (COVID-19) in China: A Report of 1014 Cases

Cascella M, Rajnik M, Cuomo A, et al. Features, Evaluation and Treatment Coronavirus (COVID-19) [Updated 2020 Mar 8]. In: StatPearls [Internet]. Treasure Island (FL): StatPearls Publishing; $2020 \quad$ Jan-. from: https://www.ncbi.nlm.nih.gov/books/NBK554776/

Clemente, F. and Sauer, W. J. 1976. Life Satisfaction In The United States. Journal Of Social Forces. 54 (3): 621- 631.

Creswell, J. W., \& Miller, D. (2000). Determining validity in qualitative inquiry. Theory Into Practice, 39(3), 124-130.

Creswell, J. W., \& Plano Clark, V. L. (2011). Designing and conducting mixed methods research (2nd ed.). Thousand Oaks, CA: Sage.

Creswell, J. W., Seagren, A., \& Henry, T. (1979). Professional development training needs of department chairpersons: A test of the Biglan model. Planning and Changing, 10, 224237.

Ghebreyesus, Tedros AdhanomDirector-General of the World Health Organization 2020 Coronavirus infections-More than just the common cold, JAMA, 323(8):707-708, 2020 DOI: https://doi.org/10.1001/jama.2020.0757

Ismail Sabri bin Yaakob,(2020)Menteri Pertahanan Malaysia ". Parliament of Malaysia. Retrieved 16 July 2020.

Ismail Sabri,Menteri Pertahanan Malaysia Timbalan Menteri Ikhmal Hisham". BH Online (in Malay). 9 March 2020. Retrieved 11 March 2020

Ismail A, Yao AYE, Lai-Kuan K, Soon-Yew J., 2010a. Occupational stress features, emotional intelligence and job satisfaction: An empirical study in private institutions of higher learning. Scientific e-Journal of Management Science 16(5), 5-33.

Ismail A, Abu HN, Chin YF, Ismail Y, Abu SAJ., 2013. Job stress as a predictor of Employee health. Studies in Business and Economics 8, 20-34.

Ilhaamie Abdul Ghani Azmi dan Wan Suryati Wan Ahmad., 2008. Pengaruh Sikap Dan Demografi ke atas Produktiviti Kerja Pensyarah Muslim: Kajian di Universiti Malaya. Shariah Journal. 16(2), 321-344. 


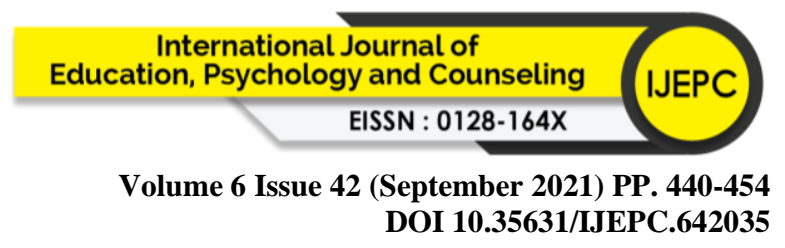

James \& Balasandran., 2009. Kepemimpinan Instruksional. Satu Panduan Praktikal. Kuala Lumpur: PTS Profesional.

Johari Hassan dan Raja Shahrina Raja Abdul Rashid. 2012. Ketagihan Penggunaan Internet Di Kalangan Remaja Sekolah Tingkatan 4 Di Bandaraya Johor Bahru. Journal of Technical, Vocational dan Engineering Education. 6: 23-43

Lau, W.W and Yuen H.A.2013. Adolescents' risky online behaviours: The influence of gender, religion and parenting style. Journal Of Computers in Human Behavior. 29: 2690-2696.

Noor Hisham Abdullah Health Director-General "Malaysian Youth Community (MYC). 21April 2020. Retrieved 29 April 2020.

Noor Hisham Abdullah"Ketua Pengarah Kesihatan" [Health Director-General].Ministry of Health (Malaysia) (in Malay). Archived from the original on 6 April 2020. Retrieved 2020-03-31

Salleh S. Keruak (2018), Malaysian Communications and Multimedia Commission Act 1998 (Act 589) ( $\underline{P D F})$. Attorney General's Chambers of Malaysia. 1 January 2006. Retrieved 25 April 201

S. Perlman, Another decade, another coronavirus, N. Engl. J. Med., 382:760-762, 2020 Vocational dan Engineering Education. 6: 23-43. DOI: https://doi.org/10.1056/nejme2001126

Tao Ai, Zhenlu Yang, Hongyan Hou, Chenao Zhan, Chong Chen, Wenzhi Lv, Qian Tao, Ziyong Sun, Liming Xia. Department of Radiology, Tongji Hospital, Tongji Medical College, Huazhong University of Science and Technology, Wuhan, Hubei, 430030, China (T.A., Z.Y.,C.Z.,C.C., L.X.), and Department of Laboratory Medicine, Tongji Hospital, Tongji Medical College, Huazhong University of Science and Technology, Wuhan, Hubei, 430030, China (H.H., Z.S.), Department of Artificial Intelligence, Julei Technology Company, Wuhan, 430030, China (W.L.), Division of Imaging Processing, Department of Radiology, Leiden University Medical Center, Leiden, the Netherlands

V. J. Munster et al., A novel coronavirus emerging in China-Key questions for impact $\begin{array}{llll}\text { assessment, N.Engl. } & \text { J. } & \text { Med., } & 382: 692-694,\end{array}$ DOI: https://doi.org/10.1056/nejmp2000929

Wright, K.N., \& Saylor, W.G., 1991. Male and female employees' perceptions of prison work: is there a difference? Justice Quarterly, 8(4), 505-524. 